\title{
The Typology of Organizational Forms of Companies' Integration
}

\author{
Victor S. Efremov \\ Professor, Faculty of Economics \\ RUDN University \\ Moscow, Russia \\ efremov_vs@pfur.ru
}

\author{
Irina G. Vladimirova \\ Professor, Faculty of Economics \\ RUDN University \\ Moscow, Russia \\ Vladimirova_ig@pfur.ru
}

\begin{abstract}
The objective of this work is to study the nature of economic and organizational processes that underlie the integration of companies. We believe that the lack of understanding of that nature can lead to surprising results as regards its purposes and in terms of costs and an expected effect of these. To achieve the purpose, a taxonomic analysis of $\mathbf{1 0}$ known organizational forms the companies' integration was conducted, for which at the beginning it was required to justify the characteristics that distinguish one form from another and set their domain of definition. The work provides an explanation of the characteristics chosen for taxonomic analysis as well as an interpretation of their values. The results show that despite its apparent diversity all know organizational forms of integration tend to be classified in three types: cooperative, corporate and combination types of companies' integration. In the basis of such types of forming there are processes of business collaboration, concentration and combination correspondently.
\end{abstract}

Keyword-organizational forms, integration of companies, taxonomic analysis, cooperative type of integration, corporate type of integration, combination type of integration

\section{INTRODUCTION}

In today's world one can observe a variety of forms of the companies' integration, which differ depending on the purpose of cooperation, the nature of economic relations between the parties and the extent of their independence. These are strategic alliances, consortiums, cartels, syndicates, pools, associations, corporations, conglomerates, trusts, corporations, holding companies, financial-industrial groups, integrated business groups and others. Such a diversity is explainable, on the one hand, by the evolutionary dynamics of organizational and economic conditions, and on the other, obvious commitment of companies to establishing most effective ways of cooperation in order to achieve its goals through the defence of common interests, i.e. with the attempt to co-evolution with other members of the integrated market place without a prejudice to the parties [1]. These forms, at least during the century have passed different stages of their evolution from corporations and family groups at the beginning to strategic alliances at the end [3]. It seems that in long term an integration of a company with someone similar or not on the market place somehow or other is unavoidable. And it is going to happen not just because of the fear of a competition and striving for the current position, but because of the business environment dynamics [2]. Some researchers are confident that all the organizations tend to networking and that is why they will face a problem of integration sooner or later [4].

It is noteworthy that the newly emerging forms until recently did not supplant the previous types of integrated business structures, but complement them. There was an expansion of the variety of forms as well. The nature of interlinkages between the subjects became more and more complex and very delicate, given on top of that also the possibility of the cooperation of integrated structures. Today it is obvious that the degree of organizational integration is largely dependent on the nature of interaction between the companies, which is defined as the character of arising between members of interlinkages and interdependencies, as well as ways to organize coordinated activities. There is an objective and urgent requirement for new organizational paradigms because of "the fast-changing demands of an ever more complex operating environment" [5].

Such interlinkages can be:

- $\quad$ Property, equity relationship (parent company's participation in subsidiaries' and affiliated companies' equities; the cross-shareholding system);

- Manufacturing relationship, mutual supply and commodities exchange;

- Managerial relationship - the relationship of coordination and subordination (cross-Directorate; directors of participating companies' relations constancy, a participation of parent company's representatives in the work of Directorates of affiliated companies);

- Technological relationship - provision by the parent company technologies to affiliated companies; technical cooperation;

- Financial relationship, including credit ones;

- Interpersonal communication.

Participants of the integrated formation can be connected by mutual property relations (holding of stakes, exchange of shares), reciprocal management links (representatives of one company can be incorporated in the board of directors of another one), granting various services (development of technology, information and advertising services, etc.). At that, mechanisms for the implementation of integration processes are the centralization and 
coordination of the merging companies' activities in a varying degree. More rigid integration forms of companies are based, as a rule, on the concentration of business assets and management processes that lead to the emergence of the unified company. Soft forms of companies' integration imply, first of all, coordination and/or combination of proprietary independent companies in the unified business-space.

The following table gives an idea of what are the scopes of industrial and economic activities require concentration, and what are coordination and/or combination in various forms of companies' integration (Table 1).

TABLE I. SPHERES OF ECONOMIC ACTIVITIES TO BE INTEGRATED UNDER VARIOUS FORMS OF COMPANIES' UNIFICATION

\begin{tabular}{|c|c|c|c|c|c|}
\hline \multirow[b]{2}{*}{$\begin{array}{c}\text { Forms of } \\
\text { integration }\end{array}$} & \multicolumn{5}{|c|}{ Economic activities } \\
\hline & $\begin{array}{c}\text { Manufac } \\
\text { turing }\end{array}$ & $\begin{array}{l}\text { Marke- } \\
\text { ting, } \\
\text { sales }\end{array}$ & Finance & $\begin{array}{l}\text { Accoun- } \\
\text { ting }\end{array}$ & Planning \\
\hline Concern & + & + & + & + & + \\
\hline Conglomerate & - & - & + & + & + \\
\hline Consortium & - & - & - & - & + \\
\hline Cartel & - & + & - & - & + \\
\hline Syndicate & - & + & - & - & + \\
\hline Association & - & - & - & - & - \\
\hline Trust & + & + & + & + & + \\
\hline $\begin{array}{l}\text { Strategic } \\
\text { alliance }\end{array}$ & - & - & - & - & + \\
\hline
\end{tabular}

Conventions:

$(+)$ - centralization of the given sphere of activity within the organizational form of companies' integration;

(-) - decentralization of the given sphere of activity within the organizational form of companies' integration.

\section{Methodology}

To conduct a comparative analysis, there were selected 10 characteristics, by which, on authors' opinion, one can adequately distinguish one organizational form of integration from the other. These included: 1) the degree of loss of legal independence of integrated companies; 2) the degree of manufacturing commonality; 3) degree of centralization of integrated companies' management; 4) the degree of unification of financial activities; 5) the degree of unification of marketing and sales activities; 6) the degree of participation in the capital of each other; 7) degree of centralization of the management for the companies' unification; 8) the degree of limitation of terms for existence of the integrative forming; 9) the admissibility of the companies entering into several integration unions; 10) the degree of formalization of contractual relations in the union. It was accepted to measure the values of each of these characteristics on a scale from 0 to 9. For the 1 st characteristic 0 means retaining by companies their full legal autonomy in the integration, and 9 - full loss of it. For the 2 nd characteristic 0 means complete lack of the manufacturing commonality of companies in the integration, and 9 - their full unification in a single manufacturing process. For the 3rd characteristic 0 means complete decentralization of companies' activities within the integration, and 9 -full centralization. For the 4 th characteristic 0 means the lack of commonality in the financial activity of companies within the integration, and 9 - full centralization of financial functions at the association level. For the 5th characteristic 0 means the luck of commonality in the sales activity of companies within the integration, a 9 - full centralization of sales functions at the association level. For the 6th characteristic 0 means, that it is not proposed companies to participate in the equity of each other, a 9-100 present compound of the companies' equities at the level of the parent company. For the 7 th characteristic 0 means totally decentralized management within the integration, and 9 - its full centralization with a creation of integrated management bodies on the association level. For the 8th characteristic 0 means that companies do not have plans for longstanding cooperation, what is typical for unifications aimed to solve specific problems, and 9 means the lack of specific terms and conditions for the existence of the unification created. For the 9th characteristic 0 means that companies do not have any restrictions on the entry of several associations, and 9 means the existence of formal restrictions on the entry of firms in other associations. For the 10th characteristic 0 means complete certainty of relationships and strict formalization of the conditions of the integration contract, and 9 means complete uncertainty of relationships and the absence of the strict formalization of the integration contract conditions.

In contrast to the marginal values of the characteristics on the scale $[0,9]$, which are quite simple to identify and interpret, an interpretation of intermediate values causes certain difficulties. In particular, if the preservation of the company, entered into the association, its legal independence completely interpreted as 0 , and the total loss of it - as 9, then what meaning can be given to this feature, if legally independent companies in the association form a new entity? Obviously, in this case, some of the legal autonomy of the companies in the association is objectively lost. We believe that in such a situation characteristic value can be equated to 3 .

Built by us for the purpose of the analysis the characteristic variety of known organizational forms of companies' integration is presented in Table 2 .

TABLE II. THE CHARACTERISTIC VARIETY OF KNOWN ORGANIZATIONAL FORMS ON COMPANIES' INTEGRATION

\begin{tabular}{|c|c|c|c|c|c|c|c|c|c|c|}
\hline \multirow{2}{*}{$\begin{array}{c}\text { Forms of } \\
\text { integration }\end{array}$} & \multicolumn{7}{|c|}{ Compared characteristics } \\
\cline { 2 - 13 } & $\boldsymbol{C}_{1}$ & $\boldsymbol{C}_{2}$ & $\boldsymbol{C}_{3}$ & $\boldsymbol{C}_{4}$ & $\boldsymbol{C}_{5}$ & $\boldsymbol{C}_{6}$ & $\boldsymbol{C}_{7}$ & $\boldsymbol{C}_{8}$ & $\boldsymbol{C}_{9}$ & $\boldsymbol{C}_{10}$ \\
\hline Concern & 7 & 7 & 8 & 9 & 7 & 7 & 9 & 9 & 9 & 9 \\
\hline Conglomerate & 6 & 0 & 5 & 9 & 3 & 7 & 7 & 9 & 9 & 9 \\
\hline Consortium & 1 & 7 & 3 & 3 & 0 & 2 & 4 & 3 & 0 & 3 \\
\hline Cartel & 0 & 8 & 2 & 0 & 1 & 0 & 2 & 3 & 0 & 3 \\
\hline Syndicate & 3 & 8 & 3 & 3 & 7 & 3 & 4 & 6 & 0 & 6 \\
\hline
\end{tabular}




\begin{tabular}{|c|c|c|c|c|c|c|c|c|c|c|}
\hline \multicolumn{10}{|c|}{ Table II, Cont. } \\
\hline Pool & 0 & 0 & 2 & 3 & 0 & 0 & 4 & 3 & 0 & 3 \\
\hline Trust & 9 & 8 & 9 & 9 & 9 & 9 & 9 & 9 & 9 & 9 \\
\hline Association & 0 & 5 & 1 & 0 & 0 & 0 & 2 & 3 & 0 & 3 \\
\hline $\begin{array}{c}\text { Strategic } \\
\text { alliance of } \\
\text { Investment } \\
\text { type }\end{array}$ & 0 & 5 & 3 & 3 & 4 & 0 & 4 & 6 & 0 & 6 \\
\hline $\begin{array}{c}\text { Strategic } \\
\text { alliance of } \\
\text { Non- } \\
\text { Investment } \\
\text { Type }\end{array}$ & 3 & 5 & 5 & 5 & 4 & 5 & 5 & 6 & 0 & 6 \\
\hline
\end{tabular}

A key role in conducting a comparative analysis of all the objects on the basis of their characteristic set is played by a choice of ways for measuring their degree of similarity. The formal analogue of this degree is the distance between the objects being compared, measured in the characteristic space by the rules of analytic geometry. To measure such a distance we choose so-called $L_{i}$-norm metrics:

$$
R_{i j}=\sum_{k=1}^{p}\left|X_{i k}-X_{j k}\right|
$$

The matrix of characteristic distances between organizational forms of integration, obtained on the basis of $L_{i}$-norm is as follows (Table 3 ).

TABLE III. THE MATRIX OF CHARACTERISTIC DISTANCES BETWEEN ORGANIZATIONAL FORMS ON COMPANIES' INTEGRATION

\begin{tabular}{|c|c|c|c|c|c|c|c|c|c|c|}
\hline & $\mathbf{1}$ & $\mathbf{2}$ & $\mathbf{3}$ & $\mathbf{4}$ & $\mathbf{5}$ & $\mathbf{6}$ & $\mathbf{7}$ & $\boldsymbol{8}$ & $\mathbf{9}$ & $\mathbf{1 0}$ \\
\hline $\boldsymbol{1}$ & 0,00 & 11,2 & 20,3 & 30,2 & 17,1 & 33,9 & 3,2 & 31,9 & 20,9 & 17,1 \\
\hline $\mathbf{2}$ & 11,2 & 0,00 & 22,4 & 32,3 & 23,0 & 22,6 & 14,4 & 30,2 & 20,1 & 16,4 \\
\hline $\mathbf{3}$ & 20,3 & 22,4 & 0,00 & 10,9 & 5,1 & 13,6 & 23,5 & 11,6 & 4,5 & 6,9 \\
\hline $\mathbf{4}$ & 30,2 & 32,3 & 10,9 & 0,00 & 13,1 & 10,6 & 31,4 & 3,6 & 13,1 & 16,9 \\
\hline $\mathbf{5}$ & 17,1 & 23,0 & 5,1 & 13,1 & 0,00 & 18,7 & 18,3 & 16,8 & 5,7 & 6,7 \\
\hline $\mathbf{6}$ & 33,9 & 22,6 & 13,6 & 10,6 & 18,7 & 0,00 & 37,1 & 7,6 & 13,0 & 16,8 \\
\hline $\mathbf{7}$ & 3,2 & 14,4 & 23,5 & 31,4 & 18,3 & 37,1 & 0,00 & 35,1 & 24,1 & 20,3 \\
\hline $\boldsymbol{8}$ & 31,9 & 30,2 & 11,6 & 3,6 & 16,8 & 7,6 & 35,1 & 0,00 & 11,0 & 14,8 \\
\hline $\mathbf{9}$ & 20,9 & 20,1 & 4,5 & 13,1 & 5,7 & 13,0 & 24,1 & 11,0 & 0,00 & 3,8 \\
\hline $\mathbf{1 0}$ & 17,1 & 16,4 & 6,9 & 16,9 & 6,7 & 16,8 & 20,3 & 14,8 & 3,8 & 0,00 \\
\hline
\end{tabular}

An analysis of the calculated matrix by rows with the aim to identify the most similar pairs of integrative forms, which means to find a cell in each row with the lowest value, except cells on the main diagonal of the matrix, gives the following results: 1) $1-7$ - distance is 3,2 ; 2) $2-1$ - distance is 11,2 ; 3) 3-9 - distance is 4,5 ; 4) $4-8$ - distance is 3,6 ; 5) $5-3$ - distance is
5,1 ; 6) $6-8$ - distance is 7,6 ; 7) $8-4$ - distance is 3,6 ; 8) 9-10 distance is 3,8 ; 9) $10-9$ - distance is 3,8 . These results explicitly indicate the presence of the three most homogeneous groups of organizational forms. The first group is formed by the trust (7), concern (1) and conglomerate (2). The second group is formed by the syndicate (5), consortium of (3) and strategic alliances of non-investment (9) and investment (10) types. The third group consisted of the cartel (4), association (8) and pool (6).

The softest organizational form of the companies' integration is a pool. It implies: 1) a preservation of the full legal independence for the uniting companies $\left.\left(\mathrm{C}_{1}=0\right), 2\right)$ a complete absence of any manufacturing interaction between them $\left.\left(\mathrm{C}_{2}=0\right), 3\right)$ a centralization of only certain processes related to making coordinated decisions $\left.\left(\mathrm{C}_{3}=2\right), 4\right)$ the pooling of financial resources only within the framework of the joint activity $\left.\left(\mathrm{C}_{4}=3\right), 5\right)$ the absence of the joint marketing activity $\left.\left(\mathrm{C}_{5}=0\right), 6\right)$ the absence of participation in the capital of each other $\left.\left(\mathrm{C}_{6}=0\right), 7\right)$ forming of unified bodies for joint activities' management $\left(\mathrm{C}_{7}=4\right)$, 8) short period of the unification's existence, limited by a project's timeframe $\left(\mathrm{C}_{8}=3\right)$, 9) possibility of the companies' participation in other associations $\left.\left(\mathrm{C}_{9}=0\right), 10\right)$ formalization of relations in association on the basis of a classical contract $\left(\mathrm{C}_{10}=3\right)$. Next in the strength of integrative interaction of unifying companies is an association, further cartel, strategic alliances of non-investment, consortium etc. (Figure 1).

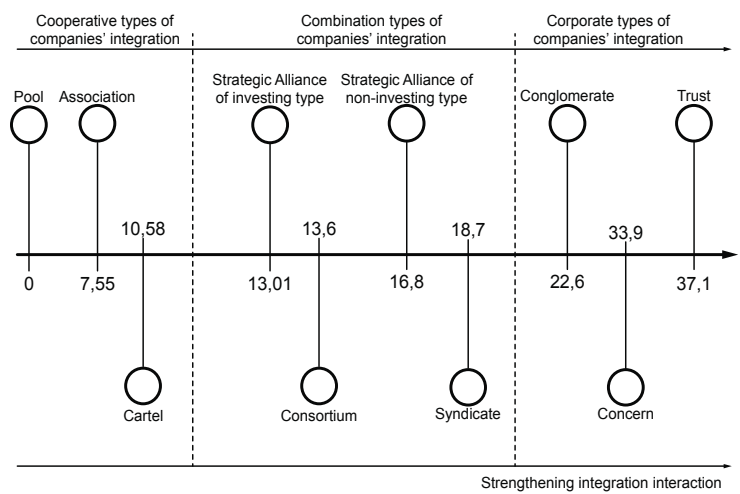

Fig. 1. The ordering forms of the companies' integration depending on the strength of integration interaction

It is easy to see that even in the order of enhancing the integration interaction of the unifying companies it is retained their division into three groups according to the degree of similarity. These groups can be defined as forms of integration: corporate, cooperative and combination types.

A representative of a group of corporate type is a concern. Its total degree of differences from the other two forms of this group is 14.42, while the conglomerate's index is 25.66, and the trust's one is 17.6. A representative of a group of cooperative type is an association. Its total degree of differences from the other two forms of this group is 11.2, while the pool's index is 14.23 , and the cartel's one is 18.3. A representative of a group of combination type is a strategic alliance of non-investment type. Its total degree of differences from the other three forms of this group is 13.98, while the 
strategic alliance of investment type's index is 17.4, the consortium's one is 16.58 and the syndicate's one is 17.52 .

In the basis of the formation of the corporate type associations there are the processes of business concentration. That is why they are distinguished by:

- Corporate integrity, based on the principle of shareholding;

- Focus on the achievement of strategic goals common for members of a unification and solving the common strategic tasks;

- Existence of a unified managerial vertical (with varying degrees of rigidity) and a single centre of control in the form of a holding company, a bank or a group of related companies;

- Unlimited nature of existence.

However, fully integrated companies tend to be slowly adapted to new technologies rather than partially integrated or non-integrated at all firms, since a change in technology for them is associated with considerable costs.

Striving to find a balance between the benefits of centralization and decentralization of management and responsibility in a business combination often leads to the selection of organizational forms of integration which occupy an intermediate position between fully centralized corporate structure and co-operation in a purely market environment. Within the form of combination type (strategic alliances, consortia, etc.) there is a possibility of mobilizing the benefits of powerful corporate structure, while maintaining the isolation of its members. After all, sometimes the state power and public opinion in the country for some reasons, first and foremost, political, unfavourably related to such forms of integration of companies, which lead to the loss of their autonomy and independence.

Of course, the boundaries between the various forms of companies' integration are rather vague. By the different specialists (both theoreticians and practitioners) they are treated sometimes ambiguous. For example, there are two completely opposing views on the relationship between strategic alliances and consortia. One opinion is that the consortium is not a strategic alliance, but the increasingly dominated view that the consortia are a distinguished type among the types of strategic alliances. Therefore, in this article, not seeking to hold a tough, well established once and for all, the line, an attempt was made to identify the most characteristic in terms of theory and practice features of the organizational forms of the companies' integration.

\section{CONCLUSION}

As a conclusion there cam be a systematization of the main forms of the companies' integration presented (Table 4).

TABLE IV. SYSTEMATIZATION OF THE MAIN FORMS OF THE COMPANIES' INTEGRATION

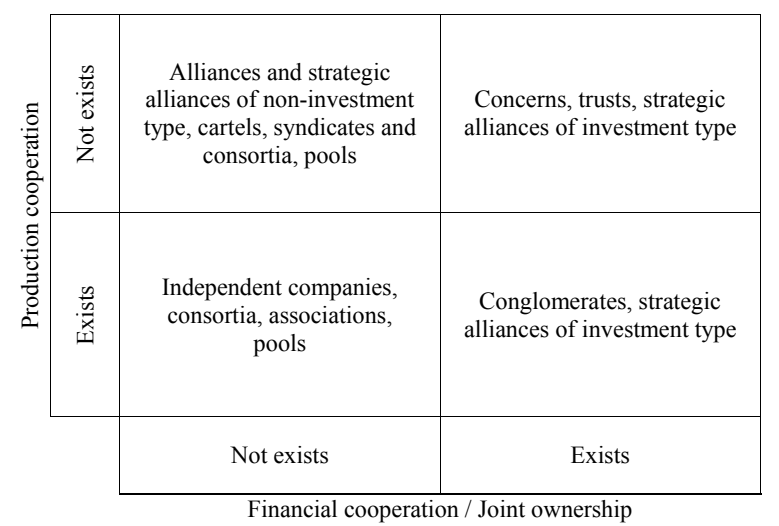

It shows that organizational forms differ mainly because of the intentions for manufacturing, financial and equity cooperation. Depending on the deepness of such a cooperation of business entities' integration may be a result of combination, collaboration or concentration of businesses.

\section{REFERENCES}

[1] Joseph M. Abe, Patricia E. Dempsey, David A.Basset (1998) Business Ecology: Giving Your Organization The Natural Edge, ButterworthHeinemann.

[2] James F. Mooore (1996) The Death of Competition: Leadership and Strategy in the Age of Business Ecosystems, John Wiley \& Sons.

[3] Chandler, A.D. (1962) Strategy and Structure: Chapters in the History of the American Industrial Enterprise, Cambridge: MIT Press.

[4] Coulson-Thomas, C. (1997) The Future of the Organization: achieving excellence through business transformation, London: Kogan Page Limited.

[5] Ghoshal, S., Bartlett, C.A., (1997) The Individualized Corporation: a fundamentally new approach to management, New York: HarperCollins Publishers. 